\title{
PEMERIKSAAN KADAR HEMOGLOBIN SEBAGAI IDENTIFIKASI AWAL ANEMIA PADA KOMUNITAS VEGETARIAN DI WILAYAH JAKARTA BARAT
}

\author{
Chairlan, Mardiana, Husjain Djajaningrat \\ Poltekes Kemenkes Jakarta III \\ email: chairlan@yahoo.com
}

\begin{abstract}
Vegetarian vegans are at risk of anemia, it maybe because the food intake lacks the nutritional components necessery for hemoglobin formation. The aims of this study is to determine of hemoglobin $(\mathrm{Hb})$ concentration in vegetarian as an indication of suffering of anemia.

The study was conducted on 57 vegetarian vegan people which was eligible by inclusioncriterion. The independent variables in this study were gender, age, and duration of being vegetarian, while the dependent variable was hemoglobin concentration. Hemoglobin concentrations of each subject was measured by Cyanmethehemoglobinmethod. Bivariate analyzed was done bychi square test and by descriptively bycomparing Hb concentration with reference value.

There are four people (7.0\%) out of the 57 subjects studied who had Hb concentrations below the reference value, consisting of one male and three female. The male and female subjects between the ages 12-25 years had the best mean Hb concentrations compared to others aged groups. T test showed no corralation between Hb concentrations with gender, age, and duration of being vegetarian $(P \geq 0.05)$. That may be due to the good-vegetarian nutritional intake.The result also show that long being vegetarian does not cause low Hb concentration, and refuse the hypothesis that it will cause low Hb concentration.
\end{abstract}

Keywords: vegetarian, hemoglobin concentration, anemia.

\section{ABSTRAK}

Vegetarian vegan berisiko mengalami anemia,hal tersebut mungkin karena asupan makanan kurang mengandung komponen gizi yang diperlukan untuk pembentukan hemoglobin. Penelitian ini bertujuan untuk mengetahui kadar hemoglobin (Hb) pada individu vegetarian sebagai indikasi anemia yang dialami.

Penelitian dilakukan terhadap 57 orang vegetarian vegan yang memenuhi kriteria inklusi.Variabel bebas dalam penelitian ini adalah jenis kelamin, umur, dan lamanya menjadi vegetarian, sedangkan variabel terikat adalah kadar hemoglobin.Kadar Hb setiap subjek diukur dengan metoda Cyanmethhemoglobin.Analisis bivariat dilakukan dengan uji chi square dan secara deskriptif dengan membandingkan kadar Hb yang diperoleh dengan nilai rujukan.

Dari 57 orang subjek yang diteliti ada empat orang (7,0\%) yang mempunyai kadar Hb di bawah nilai rujukan, terdiri atas satu orang laki-laki dan tiga orang perempuan. Subjek lakilaki dan perempuan berumur antara 12-25 tahun mempunyai rerata kadar Hb yang paling baik bila di bandingkan dengan kelompok umur yang lain.Uji chi square memperlihatkan tidak ada hubungan kadar Hb dengan jenis kelamin, umur dan lamanya menjadi vegetarian $(P \geq 0.05)$.Hal itu mungkin disebabkan asupan gizi vegetarian yang diteliti cukup baik. Hasil juga memperlihatkan bahwa lama menjadi vegetarian tidak menyebabkan kadar $\mathrm{Hb}$ menjadi rendah dan menolak dugaan bahwa akan menyebabkan kadar Hb menjadi rendah.

Kata kunci: vegetarian, kadar hemoglobin, anemia. 


\section{PENDAHULUAN}

Vegetarian menggambarkan seseorang yang tidak mengkonsumsi produk hewani, tetapi terdapat beberapa yang tetap mengkonsumsi telur dan susu serta hasil olahannya dalam makanan sehari-hari. Saat ini pola makan sebagai vegetarian semakin dikenal meluas di kalangan masyarakat (Craig W.J.2009:627S-1633S). Dari data yang ada dinyatakan lebih dari 350 juta (35\%) penduduk India merupakan vegetarian (Shridhar et al.2014, 13:55). Di Inggris jumlah vegetarian mengalami peningkatan dari $2 \%$ di tahun 1984 menjadi 14,3\% di tahun 1997 (Sabate. J., 2004). Di Taiwan sekitar 1,7 juta orang atau $13,0 \%$ penduduknya adalah vegetarian. Di Israel sebanyak 7,2\% lakilaki dan 9,8\% perempuan merupakan vegetarian. Dari sekitar 21 juta penduduk Australia ada 850.ribu orang (4\%) yang menjadi vegetarian (http://www.answers.com.05/02/2015), sedangkan di Amerika Serikat sebanyak 2,3\% (4,9 juta) penduduk dewasa Amerika Serikat vegetarian diantaranya $1.4 \%$ merupakan vegan, mereka tidak memakan daging, ikan, produk hewani maupun telur (ADA, 2009:1266) Di Indonesia sendiri diperoleh data terdaftar sebagai anggota Indonesia vegetarian society pada tahun 1998 sekitar 5000 orang dan di tahun 2007 telah meningkat menjadi 60.000 orang
(Jannah. M., 2011:5).The American Diettetic Association menyatakan orang cenderung menjadi vegetarian dikaitkan dengan manfaat kesehatan (ADA, 2009). Sementara di Indonesia alasan utama mengadopsi pola makan vegetarian berkaitan dengan alasan agama atau kesehatan (Setiarini dkk, 2013:1).

Ada penelitian yang telah dilakukan untuk mengetahui dampak pola makan vegetarian terhadap risiko anemia. Hunt . J.R. dan Roughead. Z.K.(1999)dalam penelitiannya mengungkapkan meskipun penyerapan besi-nonheme pada vegetarian lebih rendah daripada non-vegetarian, hal tersebut tidak berpengaruh terhadap kadar hemoglobin. Namun Kirchheimer. S. (2003) menyatakan bahwa $92 \%$ vegan yang diteliti di Jerman mengalami defisiensi vitamin B12 yang dapat menyebabkan anemia megaloblastik. Khusus di Indonesia Ni Putu. W. (2008), dalam penelitiannya terhadap remaja putri vegetarian di Badung Bali, memperoleh hasil ada sebanyak 30\% subjek yang kadar hemoglobin di bawah 12 gr/dl.Sebaliknya Jannah. M., dan Mulyati T. (2011) meneliti terhadap subjek vegetarian di Semarang dan surabaya meyatakan tidak ada perbedaan kadar hemoglobin antara vegetariaan vegan dengan vegetarian nonvegan, dengan rerata kadar $\mathrm{Hb}$ diatas nilai normal. 
Bertolak dari masalah tersebut dilakukan penelitian untuk mengetahui bagaimanakah kadar hemoglobin sebagai indikasi dialaminya anemia pada komunitas vegetarian di wilayah Jakarta Barat.

\section{METODE}

Penelitian dilakukan setelah memperoleh Persetujuan Kaji Etik no. LB.02.01/I/KE/L/459a/2015 tanggal 11 Agustus 2015 dari Komsi Etik Penelitian Kesehatan Politeknik Kesehatan Jakarta II. Sample penelitian adalah seluruh anggota komunitas vegetarian $\mathrm{X}$ di wilayah Jakarta Barat sebanyak 57 orang yang memenuhi kriteria inklusi, telah mendapatkan penjelasan tentang hal-hal yang berkaitan dengan penelitian dan memberikan persetujuan untuk menjadi subjek penelitian. Agustus sampai dengan November 2015. Kriteria inklusi subjek berupa: sudah menjalani pola makan sebagai vegetarian minimal 2 tahun, tidak mengalami sakit kronis/infeksi, tidak sedang hamil, nifas, menstruasi, atau perdarahan sewaktu pengambilan darah. Untuk yang masih belum dewasa mendapatkan izin menjadi subjek penelitian oleh Orang tua/wali yang bertanggung jawab. Variabel bebas dalam penelitian ini adalah jenis kelamin, umur, dan lamanya menjadi vegetarian, sedangkan variabel terikat adalah kadar hemoglobin dari subjek penelitian. Setiap responden diambil darah vena sebanyak 2,0 $\mathrm{ml}$ dan dimasukkan kedalam tabung berisi antikoagulan EDTA. Pemeriksaan kadar $\mathrm{Hb}$ dilakukan berdasarkan prinsip Cyanmethemoglobin menggunakan alat Blood Cell Counter (Sysmex type KX-21). Data yang diperoleh dianalisa menggunakan analisis univariat setiap variabel yang diteliti dalam bentuk kategorik, dan numerik. Analisis bivariat dilakukan menggunakan uji Chi square untuk mengetahui hubungan antara kadar $\mathrm{Hb}$ dengan jenis kelamin, umur dan lama menjadi vegetarian. Selanjutnya dideskripsikan dengan membandingkan hasil yang diperoleh dengan nilai rujukan yang ditetapkan oleh Kementerian Kesehatan RI.

\section{HASIL DAN PEMBAHASAN}

Pengambilan sampel darah subjek penelitian dilakukan minggu pagi (pukul 7.00 WIB) sebelum komunitas vegetarian berkumpul menjalani kegiatan meditasi. Dari 57 orang yang diteliti, karakteristik subjek berdasarkan jenis kelamin, umur, lama menjadi vegetarian diperlihatkan dalam tabel 1 . 
Tabel 1. Karakteristik subjek berdasarkan kategori jenis kelamin, umur dan lama menjadi vegetarian $(n=57)$

\begin{tabular}{lcc}
\hline \multicolumn{1}{c}{ Variabel } & Jumlah (n) & Persentase (\%) \\
\hline Jenis Kelamin & 31 & \\
$\bullet \quad$ Laki - laki & 26 & 54.4 \\
$\bullet \quad$ Perempuan & 57 & 100.0 \\
\hline Total & 10 & \\
\hline Umur & 17 & 17.6 \\
- Remaja & 30 & 29.8 \\
- Dewasa & & 52.6 \\
$\bullet \quad$ Dewasalanjut & 57 & \\
& & \\
\hline Total & 11 & 100.0 \\
\hline Lama Menjadi Vegetarian & 23 & 40.4 \\
$\bullet \quad \leq 5$ Tahun & 12 & 21.1 \\
- 6-10 Tahun & 9 & 16.7 \\
- 11 - 15 Tahun & 2 & 3.5 \\
- 16-20 Tahun & & \\
\hline Total Tahun & 57 & 100.0 \\
\hline
\end{tabular}

Subjek vegetarian berjenis kelamin lakilaki dan perempuan hampir sama banyak yakni 31 orang $(54,4 \%)$ laki-laki dan perempuan 26 orang $(45,6 \%)$. Subjek sebagian besar $(52,6 \%)$ berusia antara $46-$ 65 tahun (dewasa lanjut) dan hanya 1 orang $(2 \%)$ yang berusia diatas 65 tahun. Sisanya berusia 26-45tahun (dewasa)sebanyak 17 orang (29,8\%). dan usia 12-25 tahun (remaja) sebanyak 10 orang $(17,6 \%)$.Subjek yang telah menjalani pola hidup sebagai vegetarian terbanyak selama 6-10 tahun, 24 orang (41\%) dan paling sedikit, 2 orang (3\%) selama lebih dari 20 tahun. Sisanya sebagai vegetarian kurang dari 5 tahun sebanyak 11 orang (19\%), antara 11- 15 tahun sebanyak 12 orang (21\%) dan antara 16-20 tahun sebanyak 9 orang (16\%).Dari wawancara yang dilakukan, diantara mereka ada yang mempunyai hubungan keluarga sebagi suami-istri dan anak. Subjek yang berusia dewasa ke atas umumnya bekerja di suatu perusahaan atau sebagai wirausaha dan mempunyai pendidikan formal yang cukup, minimal lulusan sekolah menengah atas (SMA), sedangkan yang remaja masih menjalani pendidikan / sekolah.

Vegetarian menggambarkan seseorang yang tidak mengkonsumsi produk hewani, tetapi terdapat beberapa yang tetap mengkonsumsi telur dan susu serta hasil olahannya dalam makanan sehari-hari. Pada penelitian ini seluruh subjek adalah 
vegetarian murni (vegan). Jenis kelamin, umur dan makanan yang dikonsumsi merupakan faktor yang berpengaruh terhadap kadar $\mathrm{Hb}$ seseorang.

Ditinjau dari variabel karakteristik pada penelitian ini, Jumlah subjek vegetarian sebanyak 57 orang, antara jenis kelamin laki-laki dan perempuan hampir sama banyak yakni 31 orang (53\%) laki-laki dan perempuan 27 orang (47\%). Proporsi ini agak berbeda dengan penelitian yang dilakukan oleh Jannah. M., (2011) terhadap vegetarian di Semarang dan Surabaya, yang mendapatkan jumlah vegetarian perempuan lebih banyak dari pada laki-laki. Dapat dinyatakan terhadap komunitas vegetarian yang diteliti, jenis kelamin tidak berkaitan dengan minat untuk menjadi vegetarian. Subjek vegetarian sebagian besar $(52 \%)$ berusia antara 46-65 tahun dan satu orang (2\%) berusia diatas 65 tahun. Sisanya berusia 26-45 tahun sebanyak 17 orang (29\%). dan usia 12-25 tahun sebanyak 10 orang (17\%). Subjek yang telah menjalani pola hidup sebagai vegetarian terbanyak selama 6-10 tahun, 24 orang (41\%) dan paling sedikit, 2 orang (3\%) selama lebih dari 20 tahun. Sisanya sebagai vegetarian kurang dari 5 tahun sebanyak 11 orang (19\%), antara 11- 15 tahun sebanyak 12 orang (21\%) dan antara 16-20 tahun sebanyak 9 orang (16\%).Apabila dikaitkan antara umur dengan lamanya menjadi vegetarian, umumnya mereka mulai menjadi vegetarian pada umur antara 40-50 tahun. Namun demikian, kalangan usia muda juga sekarang mulai banyak yang tertarik menjadi vegetarian, hal tersebut mungkin disebabkan oleh pengaruh lingkungan keluarga, kerabat, atau teman yang telah lebih dahulu menjadi vegetarian.

Seseorang menjadi vegetarian karena berbagai alasan, termasuk karena kesehatan, keyakinan agama, keperihatinan atas kehidupan hewan, kuatir adanya penggunaan antibiotik dan hormon terhadap sumber makanan, atau menginginkan cara makan yang dapat menghindari penggunaan sumber alam secara berlebihan (Havard Health Publications , 2009). Pada komunitas yang diteliti kemungkinan alasan utama menjadi vegetarian karena menginginkan hidup sehat dan juga alasan agama, karena subjek sebagian besar adalah WNI keturunan atau etnis china dan non-muslim. Hal ini sejalan dengan pernyataan (Setiarini dkk, 2013:1), bahwa di Indonesia alasan utama mengadopsi pola makan vegetarian adalah alasan agama atau kesehatan. Disamping itu sepertinya faktor hubungan kekeluargaan berperan dalam yang menentukan pilihan sebagai vegetarian, karena pada komunitas yang diteliti 
banyak yang satu sama lain mempunyai hubungan keluarga.

Tabel 2. Nilai minimum, maximum, rerata kadar hemoglobin dan nilai $p$ berdasarkan karakteristik subjek penelitian $(N=57)$

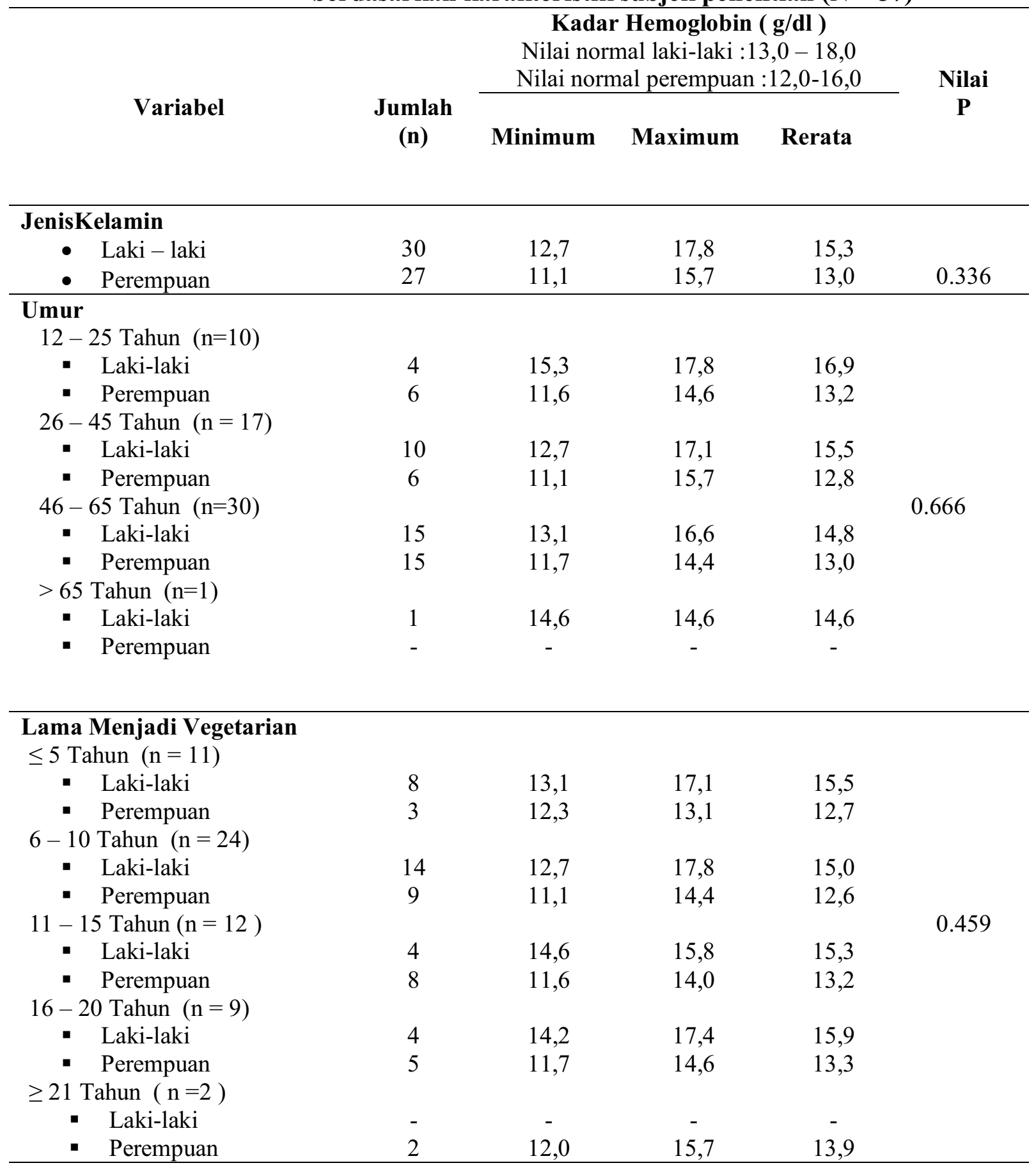

Hemoglobin berfungsi sebagai transportasi oksigen (O2). Pengukuran kadar $\mathrm{Hb}$. yang dianjurkan oleh WHO adalah metoda Cyanmethemoglobin
(Kresno, S.B. 1996 : 15). Nilai rujukan Hb: Pria : 13 - 18 g/dL dan pada Wanita: 12 - 16 g/dL. Kadar Hb. di bawah nilai 
rujukan dinyatakan sebagai anemia (Kemenkes RI, 2011: 11).

Dari 57 orang subjek yang diteliti adaempat orang $(7,0 \%)$ yang mempunyai kadar $\mathrm{Hb}$ di bawah nilai rujukan. Ke empat orang tersebut terdiri atas satu orang lakilaki dalam kelompok umur 26-45 tahun (dewasa)telah menjadi vegetarian antara 610 tahun mempunyai kadar $\mathrm{Hb} 12,7 \mathrm{~g} / \mathrm{dL}$ dengan nilai rujukan minimal 13,0 g/dL.Tiga orang yang lain berjenis kelamin perempuanmasing-masing satu orang berasal dari kelompok umur 46-65 tahun (dewasa lanjut) telah menjadi vegetarian antara $11-15$ tahun mempunyai kadar Hb. 11,7 g/dl.Satu orang dari kelompok umur 26-45 tahun(dewasa) telah menjadi vegetarian antara $6-10$ tahun mempunyai kadar $\mathrm{Hb}$ 11,1 g/dl., dan satu orang dari kelompok umur $16-20$ (remaja) tahun mempunyai kadar Hb. 11,6 $\mathrm{g} / \mathrm{dl}$.

Ditinjau dari variabel jenis kelamin, umur dan lamanya menjadi vegetarian, maka rerata kadar $\mathrm{Hb}$ dari subjek penelitian berada di atas nilai rujukan. Subjek berjenis kelamin laki-laki mempunyai rerata kadar $\mathrm{Hb}$ yang cukup baik yaitu 15,3 g/dl ( nilai rujukan : 13,0 - 18,0 g/dl), subjek berjenis kelamin perempuan mempunyai rerata kadar $\mathrm{Hb}$ 13,0 ( nilai rujukan 12-16 g/dl). Subjek laki-laki dan perempuan berumur antara 12-25 tahun mempunyai rerata kadar $\mathrm{Hb}$ yang paling baik bila di bandingkan dengan kelompok umur yang lain, hal ini mungkin disebabkan kelompok usia 12-25 tahun merupakan remaja dan dewasa muda yang metabolism tubuhnya masih sangat baik dan kemampuan eritropoiesis (pembentukan sel darah) berfungsi dengan baik.

Hasil uji chi square memperlihatkan tidak ada hubungan antara jenis kelamin vegetarian dengan kadar $\mathrm{Hb}$ (nilai $\mathrm{p}=$ 0,336 ). Hal ini berarti baik pada vegetarian laki-laki maupun perempuan mempunyai kadar $\mathrm{Hb}$ yang tidak berbeda. Padahal referensi dinyatakan Jenis kelamin merupakan salah satu faktor terhadap kadar hemoglobin, sehingga nilai rujukan kadar $\mathrm{Hb}$ antara laki-laki dengan perempuan berbeda. Kadar $\mathrm{Hb}$ dapat dipengaruhi oleh hormon androgen melalui peningkatan pembentukan sel darah merah sehingga laki-laki memiliki kadar hemoglobin sekitar 1-2 gr/dL lebih tinggi dibanding wanita. (Gibson RS. 2005). Perbedaan nilai ini secara berangsurangsur akan berkurang seiring dengan meningkatnya umur.

Dari analisis Uji statistik chi square juga dinyatakan tidak ada hubungan antara umur dengan kadar $\mathrm{Hb}(\mathrm{p}=0,666)$. Padahal Guyton AC, dan Hall JE. (1997), menyatakan kadar $\mathrm{Hb}$ dipengaruhi oleh 
umur. Pada dewasa muda umumnya metabolisme hormonnya masih baik.Semakin tua, komponen pembentuk hemoglobin dan hormon yang berpengaruh pada eritropoesis, seperti eritropoetin, mutunya menurun.

Analisis uji chi square juga memperlihatkan tidak ada hubungan antara lamanya menjadi vegetarian dengan kadar $\mathrm{Hb}(\mathrm{p}=0,459)$. Hasil ini memperlihatkan bahwa lama menjadi vegetarian tidak menyebabkan kadar $\mathrm{Hb}$ menjadi rendah dan membantah dugaan bahwa akan menyebabkan kadar $\mathrm{Hb}$ menjadi rendah. Secara deskriptif ternyata pada subjek laki-laki rerata kadar $\mathrm{Hb}$ antar kelompok lamanya menjadi vegetarian tidak terlalu berbeda. Kadar terendah ada pada kelompok lama menjadi vegetarian 6-10 tahun adalah 15,0 g/dl dan kadar tertinggi ada pada kelompok lama menjadi vegetarian 16-20 tahun adalah 15,9 g/dl. Rerata kadar $\mathrm{Hb}$ subjek perempuan ditinjau antar kelompok berdasarkan lamanya menjadi vegetarian juga keseluruhannya berada dalam kisaran nilai rujukan. Ada dua orang perempuan yang telah menjadi vegetarian lebih dari 20 tahun ternyata rerata kadar $\mathrm{Hb}$ nya13,9 $\mathrm{g} / \mathrm{dL}$ atau berada dalam kisaran nilai rujukan.

Craig W.J. (2009) menyatakan anemia pada vegetarian karena kurangnya asupan protein, vitamin B12 dan zat besi-hem untuk pembentukan hemoglobin karena bahan-bahan tersebut berasal dari produk hewani. Asupan gizi juga merupakan salah satu faktor yang mempengaruhi kadar hemoglobin. Dibutuhkan zat gizi yang adekuat agar pembentukan hemoglobin dan produksi sel darah merah berjalan dengan baik (Gibson R.S ., 2005:446-9). Vann. M.R., (2010) menyatakan potensi anemia dapat diatasi dengan cara vegetarian harus tetap memperhatikan keseimbangan diet dengan mendapatkan asupan zat besi dan vitamin B12 dari sumer lain. Protein, zat besi, vitamin B12 dan folat merupakan bahan-bahan yang penting untuk sintesis hemoglobin, pada vegetarian vegan diperoleh dari asupan gizi nabati, dan mungkin ditambah dengan mengkonsumsi suplemen.Protein harus dalam jumlah yang mencukupi agar sintesis hemoglobin berjalan dengan baik karena protein memiliki peran yang penting pada absorbs dan transportasi besi. Sebaliknya, jika protein cukup tetapi besi dalam tubuh tidak memadai maka protein juga tidak akan berperan sebagaimana mestinya. Besi yang diasup berasal dari besi non-heme saja yang terdapat pada makanan nabati, seperti sereal, kacangkacangan, sayuran hijau, dan beberapa jenis buah-buahan.Kekurangan zat besi 
kronik dapat menyebabkan anemia hipokrom mikrositik.

Vitamin B12 memiliki peranan yang sangat penting dalam meningkatkan pembentukan dan pematangan sel darah merah.Defisiensi vitamin B12 dapat menyebabkan kegagalan pematangan dalam proses eritropoiesis.Meskipun Asupan vitamin $\mathrm{B}_{12}$ sedikit, tubuh hemat dalam penggunaan vitamin $B_{12}$, yaitu simpanan vitamin $\mathrm{B}_{12}$ dapat bertahan hingga 10 tahun. Oleh karena itu, meskipun asupan vitamin $\mathrm{B}_{12}$ kurang dari kebutuhan, tubuh tetap dapat memenuhi melalui simpanan vitamin $\mathrm{B}_{12}$. Interaksi antara berbagai zat gizi dapat meningkatkan kualitas zat gizi tersebut dalam tubuh sehingga tubuh dapat memanfaatkannya secara optimal(Anderson JJB. 2004: 135; Whitney E, Rolfes SR. 2008: 195-6). Pemanfaatan zat gizi yang optimal menyebabkan sintesis hemoglobin dalam tubuh juga berjalan dengan baik.

Pada penelitian ini kemungkinan vegetarian telah mempunyai pengetahuan yang cukup mengenai gizi yang baik. Peranan pengetahuan dan persepsi yang baik akan mempengaruhi perilaku makan yang baik (Kanashiro . 2003: 133:3978S3991S). Di dalam hal ini subjek menjalani pola makan dengan asupan gizi yang baik. Oleh karena itu kadar hemoglobin vegetarian yang diteliti, umumnya berada dalam kategori normal. Dari wawancara yang dilakukan diketahui umumnya subjek merupakan individu yang berpendidikan dan pengetahuannya mengenai gizi cukup baik. Terlihat penerapannya ditempat komunitas berkumpul melakukan kegiatan meditasi, juga ada penjualan makanan olahan khusus vegetarian. Kemungkinan lain aktifitas meditasi juga berpengaruh positif terhadap hemopoiesis.

\section{SIMPULAN}

Dari 57 orang subjek yang diteliti ada empat orang $(7,0 \%)$ yang mempunyai kadar $\mathrm{Hb}$ di bawah nilai rujukan. Ke empat orang tersebut terdiri atas satu orang lakilaki dan tiga orang perempuan. Subjek laki-laki dan perempuan berumur antara 12-25 tahun mempunyai rerata kadar $\mathrm{Hb}$ yang paling baik bila di bandingkan dengan kelompok umur yang lain. Hasil uji statistik chi square, juga memperlihatkan bahwa tidak ada hubungan kadar $\mathrm{Hb}$ dengan jenis kelamin, umur dan lamanya menjadi vegetarian . Lama menjadi vegetarian tidak menyebabkan kadar $\mathrm{Hb}$ menjadi rendah dan menolak dugaan bahwa akan menyebabkan kadar $\mathrm{Hb}$ menjadi rendah. Untuk itu perlu penelitian lanjut yang 
mengkaitkan parameter hematologi dengan pola makan vegetarian.

\section{DAFTAR RUJUKAN}

ADA. 2009. Position of the American Dietetic Association: Vegetarian Diets. J Am Diet Assoc. :1266-1282. $-48$

Anderson JJB.2004. Minerals. In: Mahan LK, Stumps SE, editors. Krause's food, nutrition, and diet therapy. 11th ed. Philadelphia: Saunders;.p.135

Craig W.J.2009. Health effects of vegan diets. $\quad A m \quad J \quad C l i n$ Nutr;89(suppl):1627S-33S.

Craig. W.J. 2009. Health effects of vegan diets. . Am J ClinNutr.;59:1627 $163 \mathrm{~S}$.

Craig W.J. 1994. Iron status of vegetarians. Am J Clin Nutr.;59(5 Suppl):1233S $1237 \mathrm{~S}$.

Gibson RS.2005. Principle and nutritional assesment. 2nd ed. New York: Oxford University Press; p.446-9.

Hunt . J.R. dan Roughead. Z.K. 1999. Nonheme-iron absorption, fecal ferritin excretion, and blood indexes of iron status in women consuming controlled

Lactoovo vegetarian diets for $8 \mathrm{wk}$. Am J Clin Nutr 1999;69:944-52

Jannah.M.da Mulyati. T., 2011. Perbedan asupan zat gizi dan non-gizi yang berkaitan dengan kadar hemoglobin vegetarian, vegan dan non vegan. Artikel Penelitian. FK Univ. Dipenogoro, semarang, :5.

Kirchheimer. S. 2003. Vegetarian Diet and B12 Deficiency. Vitamin B12 Deficiency Seen in All Types of Vegetarians. https://www.webmd.com/foodrecipes/news/20030618/vegetariandiet-b12-deficiency.

Kresno, S.B., 1996. Pengantar Hematologi dan Imunohematologi. BP-FKUI Jakarta., Hal. 15-17.

Kemenkes RI. 2011. Pedoman Interpretasi Data Klinik. Hal.9-14.

Kanashiro, Bartolini HM, Fukumoto RM, Uribe MN, Robert TG, Rebecca C, 2003. Formative research to develop a nutrition education intervention to improve dietary iron intake among women and adolescent girls through community kitchens in Lima, Peru. Am J ClinNutr; 133:3978S-3991S.

Ni Putu. W. 2008, Asupan zat gizi dan kejadian anemia pada remaja putri vegetarian di Kabupaten Badung Propinsi Bali. Tesis. Universitas Gadjah Mada.

Setiarini,A.,Utari,D.M.,Marditalah, Putra, W.K.Y., Sudiarti, T., 2013. Development of food pyramide for vegetarian in Indonesia.Veg. Nutr $J .: 1$

Shridhar K, Dhillon PK, Bowen L, Kinra S, Bharathi AV, Prabhakaran D, Reddy KS, Ebrahim S. 2014. Nutritional profile of Indian vegetarian diets-the Indian Migration Study (IMS). Nutr J.;13:55.

Sabate. J.2001. Vegetarian nutrition. USA: CSC Press..Hlm. 3-6,302-305. http://www.answers.com. diakses/05/02/2015, How many vegetarian are there in Australia .

Whitney E, Rolfes SR. 2008. Understanding nutrition, 11th ed. USA: Thomson Wadsworth; p.195-6. 